\title{
Influence of Feeding Pattern and Fasting upon the Serum IRI and HGH Responses in Healthy Subjects
}

\author{
Michiko NAKAJIMA \\ Department of Internal Medicine, Keio University, School of Medicine, Tokyo, Japan \\ (Director : Professor Seiichi Asano, M.D.)
}

It has been shown in animal experiments that changing the time distribution of food intake causes a change in the metabolic state, and gorging is more likely to cause obesity and enhance lipogenesis, compared with nibbling. This effect of gorging has been ascribed to the difference in specific dynamic action (SDA).

The present study was undertaken to clarify the influence of a change in feeding frequency and fasting upon IRI and $\mathrm{HGH}$ as well as blood sugar and FFA levels. Five healthy males and three healthy females were used as subjects. A prescribed diet of 2238 calories containing $93 \mathrm{gm}$ of protein, $59.7 \mathrm{gm}$ of fat and $330 \mathrm{gm}$ of carbohydrate was given in two, three and six meals a day. In the study of the fasting state, the subjects were made to fast for 36 hours. The following results were obtained.

1. Blood sugar and IRI increased after each meal, but the increase was greater after the evening meal than morning and afternoon meals. The highest levels were obtained after the evening meal on 2 meals a day schedule. They declined gradually during fasting.

2. There was no difference in the mean 24-hour blood sugar levels regardless of the frequency of food intake, whereas the mean 24-hour IRI levels became higher as the daily intake was divided into fewer portions.

3. FFA declined after each meal and rose thereafter, and remained high during the night. FFA levels tended to be higher as frequency of meals decreased.

4. The fluctuation of $\mathrm{HGH}$ varied from one individual to another, but, in general, there was a larger fluctuation during fasting than during the day when the subjects took meals. There was no remarkable difference in the type of HGH changes dependent upon the frequency of meals, however.

The results appear to indicate that an increased release of insulin induced by food intake after a longer interval following the previous meal plays an important role in the mechanism of SDA of the meal and in causing obesity in gorging.

(See pp. 550 560) 


\section{血清インスリン及び成長ホルモンに及ぼす 食事回数と絶食の影響}

慶大内科 (指導 浅野誠一教授)

中島倫子

(昭和46年 6 月 21 日受付)

8 名の健康者に対して，同一食事を 2，3，6回に分割投与し，また 36 時間絶食 を行い血清 IRI， $\mathrm{HGH}$ の変化を観察した。食事回数の少いほど IRI は高値を示し, 特に朝, 昼食後に比し夕食後に著 しかつた. HGH には食事回数による差はあまり認められなかつたが, 絶食時高値であつた. 食事回数 を少なくすると肥満しやすいといわれており, 従来 SDA の差によると考えられているが, 著者の成績 からはインスリン反応の差加関与すると考えられる。

序論

食事回数の変化は代謝䎲種々の変化を与えることが注目され，普通 1 日中自由に食事をする（nibbling） rats を, 1 日に $1 〜 2$ 時間のみ食事を掑取する (gorging) ように訓練すると, 肥満, 高血圧, 糖尿病や動 脈硬化になりやすいととが知られている

Van Putten $ら^{3)}$ は hypothalamic-hyperphagic syndrome の rats は 1 日に 1 回で食事をとり, 対照に比 し 2 倍の体脂肪の增加を認め, さらに 2 回に食事を与えるようにすると, 体脂肪の增加は 1 回食ほどではな いと述べている. Cohn \& Joseph2) は 1 日 1 回食の rats は, 自由に食事を摄取できる rats 亿比し 50〜100 \%の体脂肪增加, lipogenesis 亿必要な醉素活性の增加, 蛋白合成の低下などを認め, 食事回数を少なくす ると掑取カロリーが経済的に用いられ，また中間代謝課程に変化を及ぼすという。

人間でも食事回数の少いものに耐糖能異常や高コレステロール血症を認め ${ }^{3) \sim 9)}, 1$ 日の食事が一定であつ ても，それを少い回数で摂取するとエネルギー代謝が経済的に行われ，対照に比し肥るてとが知られている 4)10．しかし，その機構はまだほとんぞ解明されておらず，てとにホルモン作用についての知見は少い．

著者は食事回数の変化がインスリン及び成長ホルモンに与える影響をみる目的で, 健康者 8 名に, 1 日の 摆取食事を同一とし，それを 6 回，3回，2回に分割投与し，さらに36時間の絶食を行い，血清インスリン (以下 IRI と省略), 血清成長ホルモン（以下 $\mathrm{HGH}$ と省略）の变動について観察した。同時に血糖, 血 清遊離脂酸（以下 FFA と省略）を測定し，てれら相互の関係について観察した。

対 象

糖尿病家系を有しない健康研究室員男 5 名，女 3 名，計 8 名について観察した。年令は $22 \sim 44$ 才 (平均 27.6 才), 身長 $152 \sim 170 \mathrm{~cm}$ (平均 $167.4 \mathrm{~cm}$ )，体重 $43 \sim 68 \mathrm{~kg}$ （平均 $54.4 \mathrm{~kg}$ ）で，肥満度は松木の標準体重表 ${ }^{11}$ により算出すると， $-22 \%$ + $11 \%$ (平均 $-8.8 \%$ ) である.

\section{実 験 方 法}

1 日に摂取せしめた食事の食品構成は食パン $360 \mathrm{gm}$, 牛乳 $360 \mathrm{gm}$, 卵 $150 \mathrm{gm}$, コンビーフ $75 \mathrm{gm}$, チーズ $42 \mathrm{gm}$ ，ネーブルオレンジ $720 \mathrm{gm}$, 珘ジャム $60 \mathrm{gm}$ よりなる. 1 日量として糖質 $330 \mathrm{gm}$. 蛋白質 $93 \mathrm{gm}$. 脂 
質 $59.7 \mathrm{gm}$, 熱量2238カロリーで, 乙れを 6 回食では 6 等分, 3 回食では 3 等分, 2 回食では 2 等分して与 えた。すなわち各実験における 1 回の糖質は各々 $55 \mathrm{gm}, 110 \mathrm{gm}, 165 \mathrm{gm}$ である.

被験者は実験前日の午後 8 時より禁食とした。食事時刻は 2 回食では 9 時, 19時, 3 回食では 9 時, 13 時, 19時， 6 回食では 9 時，11時，13時，15時，17時，19時とした。なお飲水は制限しなかつた。採血時刻は原 則として食前, 食後 1 時間, 2 時間, 午後11時, 翌午前 2 時, 4 時, 8 時とし, 肘静脈より採血した。就葠 は午後11時とした。前日の食事は自由とし，実験当日の勤務は平常通りとした。各実験は 1 週間以上の間隔 をおいて行なつた。ささらに，前日午後 8 時より36時間の絶食を試みた。

血糖は Hoffman 変法， $|\mathbb{R I}|^{12)}, \mathrm{HGH}^{13)}$ は二抗体法, FFA は Itaya-Ui ${ }^{14)}$ 法で測定した。

\section{結果}

2 回食, 3 回食, 6 回食及び絶食時の血糖, IRI, FFA, HGH の各測定時の平均值を Table 1 亿示し た.

\section{1. 血糖}

血糖は食事摄取時，毎食後上昇し，その後下降，夜間にはほとんど変動が認められなかつた。

2 回食, 3 回食, 6 回食を比較してみると (Fig. 1), そのいずれにおいても, 朝食後, 昼食後に比し夕食 後の血糖上昇が著しい. 食後 1 時間の血糖値でみると， 3 回食では朝食後 $88.6 \pm 11.2 \mathrm{mg} / \mathrm{dl}$, 昼食後 $99.8 \pm$ $5.1 \mathrm{mg} / \mathrm{dl}$ に比し, 夕食後は $125.2 \pm 6.7 \mathrm{mg} / \mathrm{dl}$ であり, 前 2 者より有意に高い $(\mathrm{p}<0.02, \mathrm{p}<0.01) .2$ 回食 では朝食後 $81.6 \pm 6.7 \mathrm{mg} / \mathrm{dl}$ 亿比し, 夕食後 $168.7 \pm 9.6 \mathrm{mg} / \mathrm{dl}$ と $(\mathrm{p}<0.01), 6$ 回食では昼食後 $96.2 \pm 3.7 \mathrm{mg}$ $/ \mathrm{d} l$ に比し, 夕食後 $110.1 \pm 4.4 \mathrm{mg} / \mathrm{dl}$ と $(\mathrm{p}<0.05)$, 夕食後の血糖上昇は有意に高い.また，夕食後の血糖 上昇は食事回数の少いほど著しく，夕食後 1 時間の血糖についてみると， 2 回食は $168.7 \pm 9.6 \mathrm{mg} / \mathrm{d}$ であり， 3 回食 $125.2 \pm 6.7 \mathrm{mg} / \mathrm{dl}, 6$ 回食 $110.1 \pm 4.4 \mathrm{mg} / \mathrm{d}$ 亿比し有意に高值を示した $(\mathrm{p}<0.05, \mathrm{p}<0.01) .3$ 回食 は 6 回食に比し高值であるが, 有意差はなかつた。

各個人の血糖値をみても 3 回食及び 6 回食では, 夕食後血糖は各々 $112 \sim 166 \mathrm{mg} / \mathrm{dl}, 93 \sim 128 \mathrm{mg} / \mathrm{dl}$ の範 囲にあるが， 2 回食では132〜 198 $\mathrm{mg} / \mathrm{dl}$ であり，8 名中 4 名が $180 \mathrm{mg} / \mathrm{dl}$ 以上の高值を示した。

絶食では午前 8 時の $86.5 \pm 1.1 \mathrm{mg} / \mathrm{dl}$ から漸减し，翌午前 8 時には $63.9 \pm 2.9 \mathrm{mg} / \mathrm{dl}$ となつた。

\section{IRI}

IRI は Fig. 2 亿示すように, 6 回食では朝食前 $7.5 \pm 1.2 \mu \mathrm{U} / \mathrm{ml}$ 亿比し, 朝食後 $18.2 \pm 0.5 \mu \mathrm{U} / \mathrm{ml}$, 昼食 後 $17.1 \pm 3.6 \mu \mathrm{u} / \mathrm{ml}$, 夕食後 $30.5 \pm 4.9 \mu \mathrm{U} / \mathrm{ml}$ であり, 3 回食では朝食後 $44.0 \pm 6.4 \mu \mathrm{U} / \mathrm{ml}$. 昼食後 $33.5 \pm$ $4.4 \mu \mathrm{U} / \mathrm{ml}$, 夕食後 $54.7 \pm 9.2 \mu \mathrm{U} / \mathrm{ml}, 2$ 回食では朝食後 $46.7 \pm 12.7 \mu \mathrm{U} / \mathrm{ml}$ 夕食後 $135.0 \pm 26 \mu \mathrm{U} / \mathrm{ml}$ と食後 上昇した。そのいずれにおいても, 夕食後の IRI 上昇は, 朝食後, 昼食後に比し大である.すすおち， 3 回食で昼食後に比し夕食後は有意に高く $(\mathrm{P}<0.02) .2$ 回食では朝食後に比し夕食後 $(\mathrm{p}<0.01), 6$ 回食では 朝食後, 昼食後に比し, 夕食後の IRI 増加は有意に大である（ $\mathrm{p}<0.01, \mathrm{p}<0.05)$.

また，夕食後 1 時間の IRI 上昇は，食事回数の少いほど大きく，2 回食では $135 \pm 26 \mu \mathrm{U} / \mathrm{ml}$ を示し， 3 回食の $54.7 \pm 9.2 \mu \mathrm{U} / \mathrm{ml}$ に比し, また, 3 回食は 6 回食の $30.5 \pm 4.9 \mu \mathrm{U} / \mathrm{ml}$ に比し, 各々有意に高值であ る $(\mathrm{p}<0.01, \mathrm{p}<0.05)$.

夜間の変動はいずれにおいても少く $10 \mu \mathrm{U} / \mathrm{ml}$ 前後である. 絶食では午前 8 時 $11.8 \pm 3.2 \mu \mathrm{U} / \mathrm{ml}$ 亿比し， 翌午前 8 時は $8.5 \pm 2.0 \mu \mathrm{U} / \mathrm{ml}$ であり漸娍している.

\section{FFA}

FFA（Fig. 3) は食後低下し，その後上昇しているが，食事回数の少いほど㢄の変動は大である．その範 囲は 6 回食では $214 \pm 12 \mu \mathrm{Eq} / \mathrm{L}$ より $324 \pm 42 \mu \mathrm{Eq} / \mathrm{L}, 3$ 回食では $277 \pm 16 \mu \mathrm{Eq} / \mathrm{L}$ より $548 \pm 38 \mu \mathrm{Eq} / \mathrm{L}, 2$ 回 食では $309 \pm 20 \mu \mathrm{Eq} / \mathrm{L} よ り 806 \pm 47 \mu \mathrm{Eq} / \mathrm{L}$ である.

夕食前, 6 回食では $342 \pm 42 \mu \mathrm{Eq} / \mathrm{L}, 3$ 回食では $548 \pm 38 \mu \mathrm{Eq} / \mathrm{L}, 2$ 回食では $806 \pm 47 \mu \mathrm{Eq} / \mathrm{L}$ であり, 夕 食前 FFA 增加は 2 回食は 3 回食に比し，また， 3 回食は 6 回食に比し有意に高い， $(\mathrm{p}<0.05, \mathrm{p}<0.05)$. 
Table 1. Blood sugar, IHI, FFA and HGH levels during four experimental schedules

\begin{tabular}{|c|c|c|c|c|c|c|c|}
\hline & Time & 8 & 10 & 11 & 13 & 14 & 15 \\
\hline 6meals $(n=8)$ & $\begin{array}{c}\text { Blood sugar } \\
\text { IRI } \\
\text { FFA } \\
\text { HGH }\end{array}$ & $\begin{array}{c}92.0 \pm 3.1 \\
7.5 \pm 1.2 \\
403 \pm 43 \\
0.3 \pm 0.2\end{array}$ & $\begin{array}{c} \\
95.0 \pm 7.5 \\
18.2 \pm 0.5 \\
214 \pm 12 \\
0.8 \pm 0.2\end{array}$ & $\begin{array}{c}91.2 \pm 4.0 \\
13.6 \pm 3.6 \\
257 \pm 20 \\
2.0 \pm 1.0\end{array}$ & $\begin{array}{c}\downarrow \\
92.0 \pm 1.6 \\
12.8 \pm 2.1 \\
267 \pm 27 \\
3.0 \pm 1.2\end{array}$ & $\begin{array}{l}\downarrow \\
96.2 \pm 3.7 \\
17.1 \pm 3.6 \\
277 \pm 27 \\
1.2 \pm 0.5\end{array}$ & $\begin{array}{c}91.4 \pm 3.3 \\
9.7 \pm 1.9 \\
300 \pm 54 \\
1.5 \pm 0.6\end{array}$ \\
\hline 3meals $(\mathrm{n}=8)$ & $\begin{array}{c}\text { Blood sugar } \\
\text { IRI } \\
\text { FFA } \\
\text { HGH }\end{array}$ & $\begin{array}{c}80.2 \pm 3.4 \\
10.0 \pm 1.5 \\
380 \pm 30 \\
2.2 \pm 0.9\end{array}$ & $\begin{array}{l}\downarrow \\
88.6 \pm 11.2 \\
44.0 \pm 6.4 \\
276 \pm 16 \\
1.3 \pm 0.3\end{array}$ & $\begin{array}{c}81.6 \pm 4.7 \\
23.5 \pm 2.8 \\
309 \pm 15 \\
3.3 \pm 1.4\end{array}$ & $\begin{array}{c}88.0 \pm 3.0 \\
12.1 \pm 0.7 \\
422 \pm 35 \\
2.8 \pm 1.0\end{array}$ & $\begin{array}{c}\downarrow \\
99.8 \pm 5.1 \\
33.5 \pm 4.4 \\
323 \pm 26 \\
1.5 \pm 0.3\end{array}$ & $\begin{array}{c}95.7 \pm 7.1 \\
26.7 \pm 4.0 \\
386 \pm 36 \\
1.7 \pm 0.7\end{array}$ \\
\hline Is $(\mathbf{n}=\mathbf{8})$ & $\begin{array}{c}\text { Blood sugar } \\
\text { IRI } \\
\text { FFA } \\
\text { HGH }\end{array}$ & $\begin{array}{c}81.7 \pm 1.6 \\
15.2 \pm 6.8 \\
406 \pm 46 \\
2.0 \pm 0.2\end{array}$ & $\begin{array}{c}\downarrow \\
81.6 \pm 6.7 \pm 12.7 \\
339 \pm 39 \\
2.1 \pm 0.4\end{array}$ & $\begin{array}{c}81.6 \pm 2.7 \\
34.0 \pm 5.7 \\
309 \pm 20 \\
1.7 \pm 0.2\end{array}$ & $\begin{array}{c}93.0 \pm 2.5 \\
24.8 \pm 5.7 \\
319 \pm 24 \\
2.0 \pm 0.2\end{array}$ & $\begin{array}{c}94.5 \pm 1.2 \\
13.0 \pm 1.8 \\
335 \pm 28 \\
7.8 \pm 4.4\end{array}$ & $\begin{array}{c}94.8 \pm 0.8 \\
8.1 \pm 2.7 \\
478 \pm 46 \\
11.6 \pm 5.9\end{array}$ \\
\hline & Time & 8 & 10 & 12 & & 14 & 16 \\
\hline Fasting $(n=8)$ & $\begin{array}{c}\text { Blood sugar } \\
\text { IRI } \\
\text { FFA } \\
\text { HGH }\end{array}$ & $\begin{array}{c}86.5 \pm 1.1 \\
11.8 \pm 3.2 \\
500 \pm 45 \\
2.5 \pm 0.5\end{array}$ & $\begin{array}{c}84.5 \pm 1.3 \\
13.0 \pm 3.4 \\
522 \pm 55 \\
4.3 \pm 0.9\end{array}$ & $\begin{array}{c}87.7 \pm 1.5 \\
12.6 \pm 2.6 \\
650 \pm 69 \\
9.6 \pm 5.5\end{array}$ & & $\begin{array}{c}84.1 \pm 2.2 \\
11.3 \pm 3.0 \\
801 \pm 38 \\
4.2 \pm 0.6\end{array}$ & $\begin{array}{c}82.6 \pm 2.6 \\
10.0 \pm 1.3 \\
758 \pm 55 \\
5.1 \pm 2.4\end{array}$ \\
\hline
\end{tabular}

\begin{tabular}{|c|c|c|c|c|c|c|c|}
\hline 17 & 19 & 20 & 21 & 23 & 2 & 4 & 8 \\
\hline $\begin{array}{l}\downarrow \\
100.6 \pm 7.5\end{array}$ & $\stackrel{\downarrow}{107.5 \pm 7.1}$ & $\begin{array}{l}\downarrow \\
110.1 \pm 4.4\end{array}$ & $100.2 \pm 4.1$ & $101.6 \pm 1.3$ & $101.2 \pm 2.0$ & $100.2 \pm 2.2$ & $95.2 \pm 2.7$ \\
\hline $18.7 \pm 2.0$ & $17.2 \pm 2.8$ & $30.5 \pm 4.9$ & $13.7 \pm 2.1$ & $8.6 \pm 1.7$ & $7.5 \pm 1.7$ & $6.6 \pm 1.3$ & $7.1 \pm 1.4$ \\
\hline $257 \pm 26$ & $324 \pm 42$ & $305 \pm 31$ & $300 \pm 20$ & $559 \pm 53$ & $650 \pm 59$ & $582 \pm 75$ & $430 \pm 67$ \\
\hline \multirow[t]{9}{*}{$4.0 \pm 1.3$} & $2.1 \pm 0.8$ & $1.0 \pm 1.0$ & $1.8 \pm 0.9$ & $14.7 \pm 3.4$ & $7.6 \pm 2.4$ & $2.5 \pm 1.2$ & $1.3 \pm 0.8$ \\
\hline & $87.6 \pm 2.8$ & $|\downarrow|$ & $117.3 \pm 8.7$ & $79.7 \pm 3.5$ & $84.3 \pm 2.3$ & $83.3 \pm 2.6$ & $84.3 \pm 2.6$ \\
\hline & $13.1 \pm 1.1$ & $54.7 \pm 9.2$ & $51.6 \pm 8.2$ & $12.6 \pm 1.1$ & $10.0 \pm 0.7$ & $10.1 \pm 1.2$ & $9.6 \pm 1.6$ \\
\hline & $548 \pm 36$ & $355 \pm 28$ & $379 \pm 34$ & $455 \pm 43$ & $705 \pm 41$ & $646 \pm 64$ & $494 \pm 60$ \\
\hline & $6.8 \pm 2.8$ & $1.7 \pm 0.1$ & $1.6 \pm 0.1$ & $13.1 \pm 3.6$ & $5.6 \pm 1.4$ & $2.6 \pm 0.4$ & $1.8 \pm 0.3$ \\
\hline & $94.2 \pm 11.9$ & $\left|\begin{array}{l}\downarrow \\
168.7 \pm 9.6\end{array}\right|$ & $114.1 \pm 5.4$ & $92.6 \pm 2.4$ & $88.0 \pm 3.1$ & $86.8 \pm 3.0$ & $90.1 \pm 1.7$ \\
\hline & $8.1 \pm 2.6$ & $135.0 \pm 26.0$ & $109.5 \pm 21.3$ & $30.8 \pm 7.4$ & $9.7 \pm 2.3$ & $12.8 \pm 4.3$ & $14.8 \pm 5.8$ \\
\hline & $806 \pm 47$ & $379 \pm 54$ & $356 \pm 28$ & $458 \pm 49$ & $567 \pm 63$ & $569 \pm 73$ & $436 \pm 42$ \\
\hline & $1.7 \pm 0.3$ & $1.7 \pm 0.3$ & $1.5 \pm 0.3$ & $10.5 \pm 3.3$ & $8.0 \pm 1.4$ & $4.6 \pm 0.8$ & $5.0 \pm 2.3$ \\
\hline 18 & & 20 & & 23 & 2 & 4 & 8 \\
\hline $80.7 \pm 2.6$ & & $76.8 \pm 2.3$ & & $74.3 \pm 3.5$ & $68.8 \pm 3.0$ & $67.1 \pm 3.0$ & $63.6 \pm 2.9$ \\
\hline $10.3 \pm 2.3$ & & $7.1 \pm 1.4$ & & $9.1 \pm 2.0$ & $10.2 \pm 2.9$ & $9.7 \pm 1.7$ & $8.5 \pm 2.0$ \\
\hline $755 \pm 44$ & & $775 \pm 48$ & & $782 \pm 24$ & $787 \pm 32$ & $853 \pm 47$ & $844 \pm 38$ \\
\hline $4.0 \pm 0.6$ & & $16.1 \pm 11.9$ & & $19.0 \pm 7.8$ & $20.8 \pm 3.3$ & $22.0 \pm 4.8$ & $12.5 \pm 2.3$ \\
\hline
\end{tabular}

(Mean \pm S.E.)

Blood sugar $(\mathrm{mg} / \mathrm{dl})$. IRI $(\mu \mathrm{U} / \mathrm{ml})$ FFA $(\mu \mathrm{Eq} / \mathrm{L})$ HGH $(\mathrm{m} \mu \mathrm{g} / \mathrm{dl}) \downarrow$ meal 
Fig. 1. Average curves of blood sugar in eight healthy subjects during four experimental schedules. Mean + S.E.

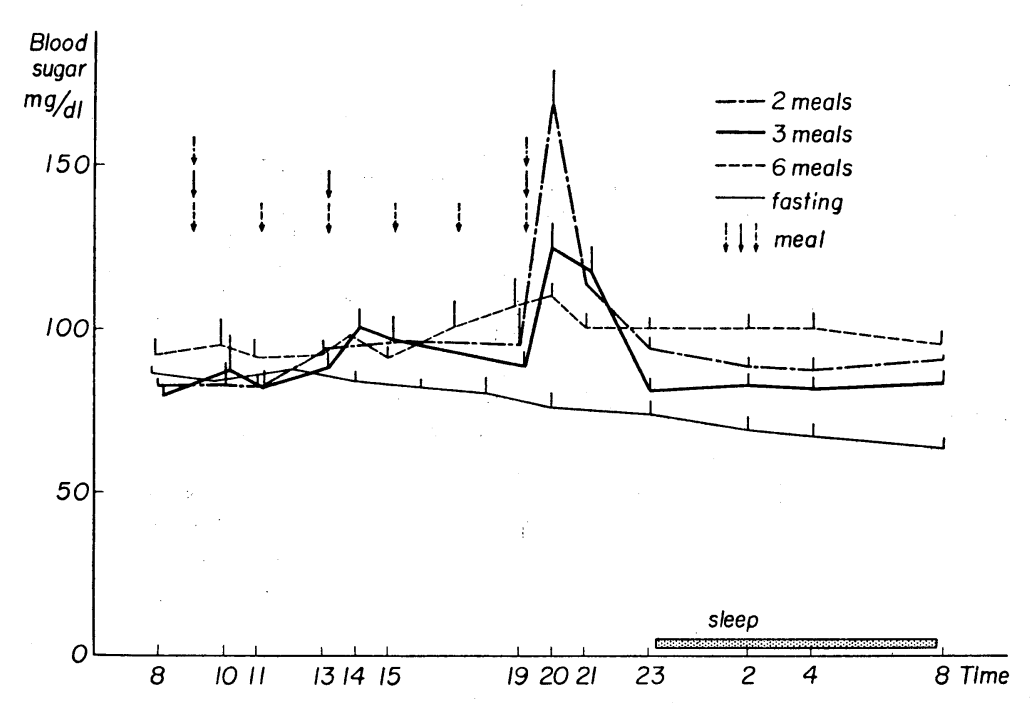

Fig. 2. Average curves of IRI in eight healthy subjects during four experimental schedules. Mean + S.E.

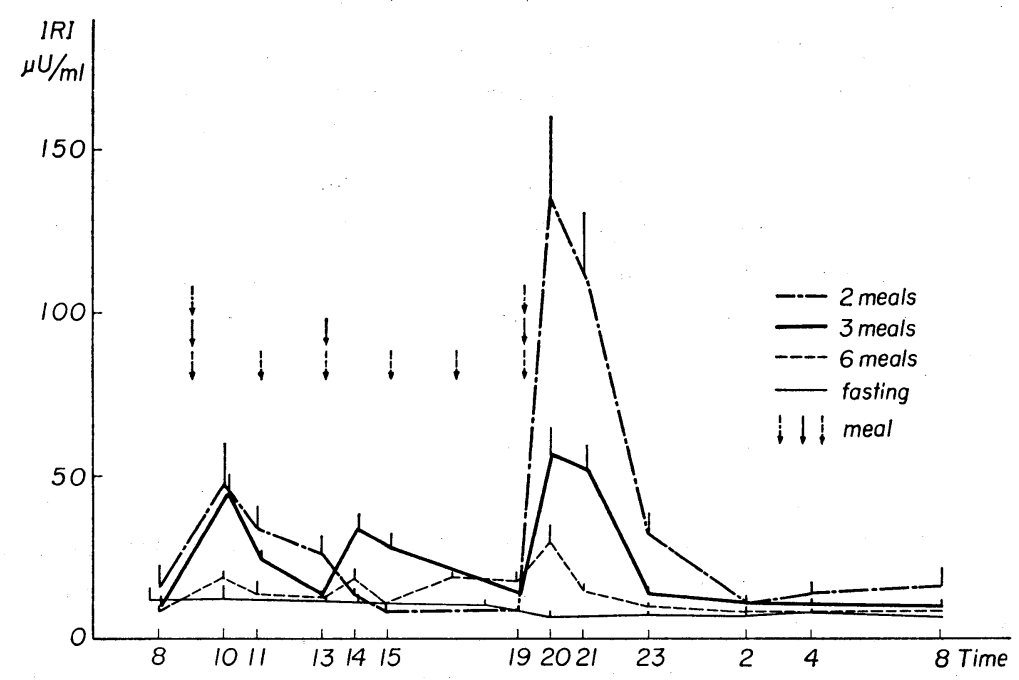

また，FFA は夜間に上昇が認められ，6 回食では $650 \pm 56 \mu \mathrm{Eq} \mu \mathrm{Eq} / \mathrm{L}, 3$ 回食では $705 \pm 41 \mu \mathrm{Eq} / \mathrm{L}, 2$ 回食 では $569 \pm 73 \mu \mathrm{Eq} / \mathrm{L}$ と最高值を示したが，てれらの差は有意ではない.

絶食時, 牛前 8 時 $500 \pm 45 \mu \mathrm{Eq} / \mathrm{L}$ より漸増し, 翌午前 8 時には $844 \pm 47 \mu \mathrm{Eq} / \mathrm{L}$ であつた. 午前 2 時, 4 時, 8 時の FFA 值は各々 $787 \pm 32 \mu \mathrm{Eq} / \mathrm{L}, 853 \pm 47 \mu \mathrm{Eq} / \mathrm{L}, 844 \pm 38 \mu \mathrm{Eq} / \mathrm{L}$ であり, 食事摂取時に比し有意 に高值である.

\section{HGH}


Fig. 3. Average curves of FFA in eight healthy subjects during four experimental schedules. Mean+S.E.

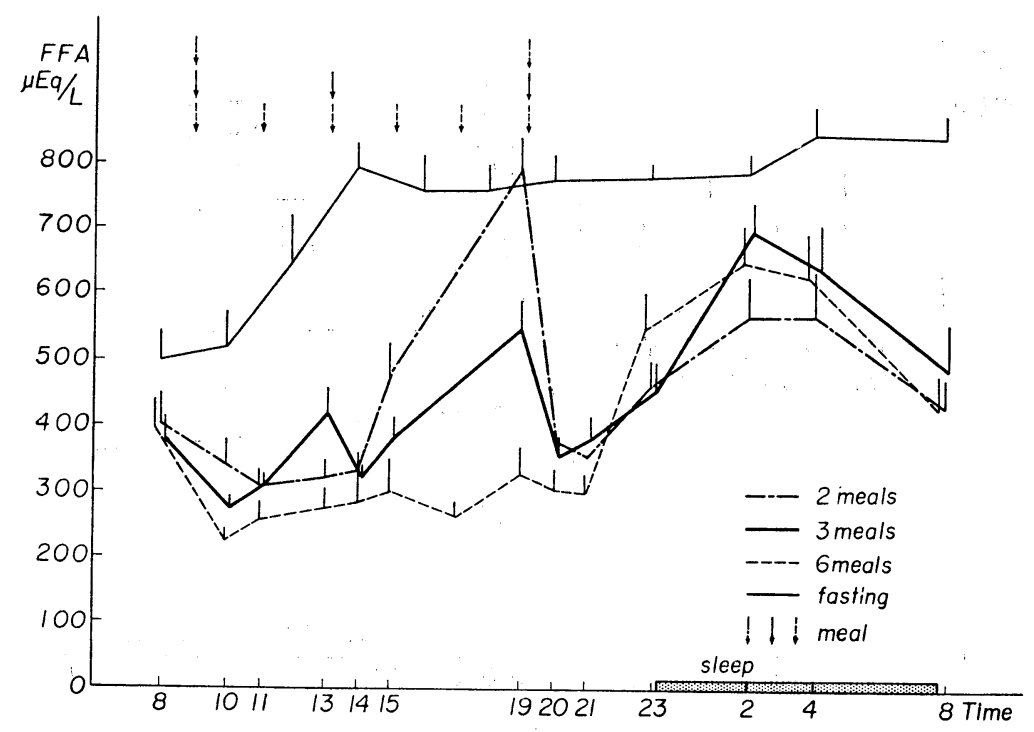

HGH の各実験における各人の変動を Fig. 4 に, 各測定時の 8 名の平均値を Fig. 5 に示した.

HGH の反応には peak が認められた. peak の現れる時刻及びその币には個人差が大きいが， 3 回食， 6 回食では食後 2 時間， 2 回食では食後 $5 \sim 6$ 時間で peak を認めた. Peak のわは 6 回食では 6-13m $\mu \mathrm{g} /$ $\mathrm{ml}, 3$ 回食では $3-26 \mathrm{~m} \mu \mathrm{g} / \mathrm{ml}, 2$ 回食では $11-51 \mathrm{~m} \mu \mathrm{g} / \mathrm{ml}$ と, 食事回数の少いほど高い傾向を示した.

各測定時の平均值についてみると, 6 回食では午後 1 時に $3.0 \pm 1.2 \mathrm{~m} \mu \mathrm{g} / \mathrm{ml}$. 午後 5 時に $4.0_{ \pm} 1.3 \mathrm{~m} \mu \mathrm{g} / \mathrm{ml}$ と増加, 3 回食では午前 11 時に $3.3 \pm 1.4 \mathrm{~m} \mu \mathrm{g} / \mathrm{ml}$. 午後 7 時 $6.8 \pm 2.8 \mathrm{~m} \mu \mathrm{g} / \mathrm{ml}, 2$ 回食では午後 2 時, 3 時に 各々 $7.8 \pm 4.4 \mathrm{~m} \mu \mathrm{g} / \mathrm{ml}, 11.6 \pm 5.9 \mathrm{~m} \mu \mathrm{g} / \mathrm{ml}$ の上昇をみたが, 食事回数による有意差は認められなかつた。

絶食では午前 10 時より peak を認め，その门は $6-100 \mathrm{~m} \mu \mathrm{g} / \mathrm{ml}$ と，食事摂取時に比し大である，午前 2 時, 4 時, 8 時の平均值は $10.2 \pm 2.9 \mathrm{~m} \mu \mathrm{g} / \mathrm{ml}, 9.7 \pm 1.7 \mathrm{~m} \mu \mathrm{g} / \mathrm{ml}, 8.5 \pm 2.0 \mathrm{~m} \mu \mathrm{g} / \mathrm{ml}$ であり, 食事摄取時に比 し有意に高值である.

\section{1 日平均値}

1 日平均血糖, IRI, FFA, HGH 值を Fig. 6 亿示した.

血糖は 6 回食, 3 回食, 2 回食において各々 $98 \pm 2.5 \mathrm{mg} / \mathrm{dl}, 92 \pm 3.1 \mathrm{mg} / \mathrm{dl}, 96 \pm 1.1 \mathrm{mg} / \mathrm{dl}$ であり, 食事 回数による差を認めなかつた。絶食では $78 \pm 1.8 \mathrm{mg} / \mathrm{dl}$ と食事掑取時に比し有意に低值である（p $<0.01 ）$.

1 日平均 IRI 值は食事回数の少いほど高值を示し， 2 回食では $35.9 \pm 4.9 \mu \mathrm{U} / \mathrm{ml}$ と 3 回食 $23.9 \pm 1.8 \mu \mathrm{U} /$ $\mathrm{ml}$ に比し，また， 3 回食は 6 回食の $13.3 \pm 1.5 \mu \mathrm{U} / \mathrm{ml}$ に比し有意に高值である $(\mathrm{p}<0.05, \mathrm{p}<0.01)$.

1 日平均 FFA 值は 6 回食, 3 回食, 2 回食において各々 $368 \pm 24 \mu \mathrm{Eq} / \mathrm{L}, 426 \pm 26 \mu \mathrm{Eq} / \mathrm{L}, 455 \pm 35 \mu \mathrm{Eq} / \mathrm{L}$ と, 食事回数の少いほど 高值 を示した. 6 回食と 2 回食の差は有意である $(\mathrm{p}<0.05)$. 絶食時の 1 日平均 FFA 值は $742 \pm 37 \mu \mathrm{Eq} / \mathrm{L}$ であり, 食事摂取時に比し高く, 2 回食との差は有意である $(\mathrm{p}<0.01)$.

1 日平均 $\mathrm{HGH}$ 值は 6 回食, 3 回食, 2 回食で各々 $3.45 \pm 0.5 \mathrm{~m} \mu \mathrm{g} / \mathrm{ml}, 3.5 \pm 0.4 \mathrm{~m} \mu \mathrm{g} / \mathrm{ml}, 4.8 \pm 0.8 \mathrm{~m} \mu \mathrm{g}$ / $\mathrm{ml}$ と食事回数の少いほど大であるが，有意差は認められなかつた：絶食時 $11.0 \pm 2.4 \mathrm{~m} \mu \mathrm{g} / \mathrm{ml}$ を示し，食 事摄取時に比し有意に高い（p<0.01），なお，いずれの実験においても，HGH 反応に男女差は認められな かつた。

\section{6. 各測定值相互の関係}


Fig. 4. Plasma HGH levels in 8 healthy subjects during four experimental schedules.
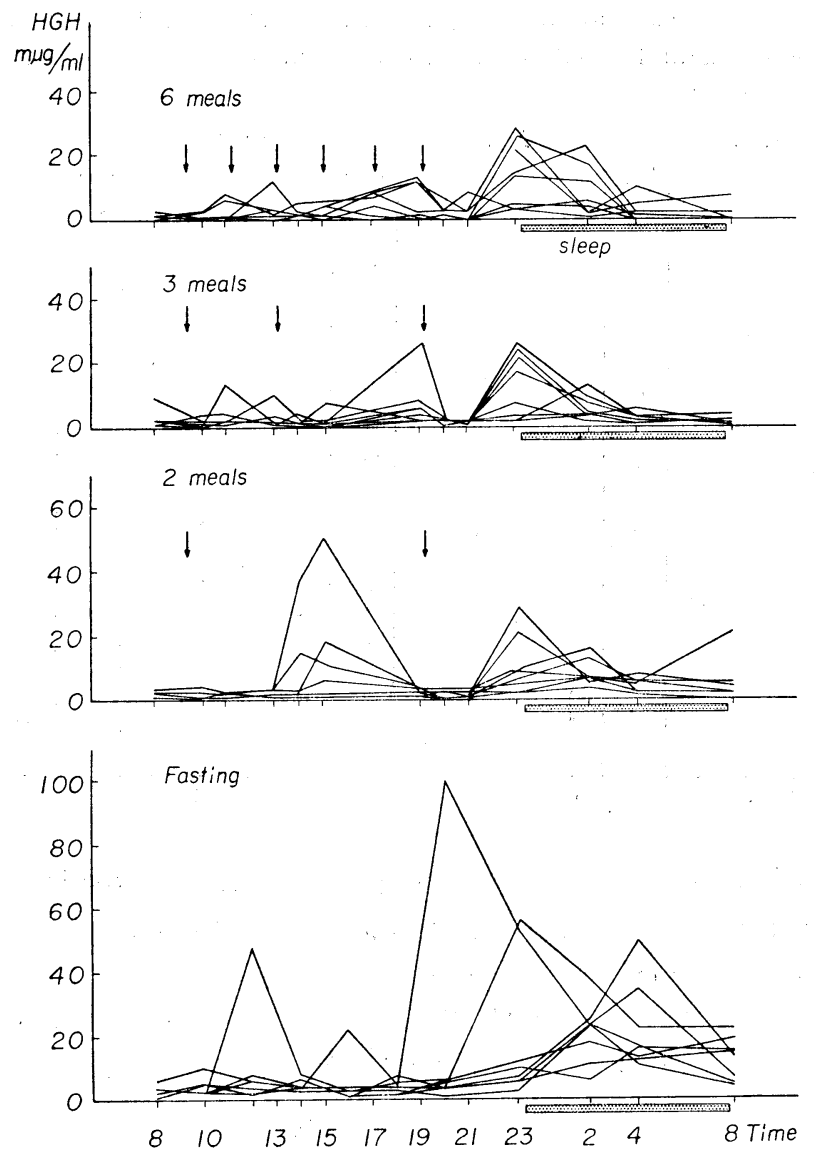

Fig. 5. Average curves of $\mathrm{HGH}$ in eight healthy subjects during four experimental schedules. Mean + S.E.

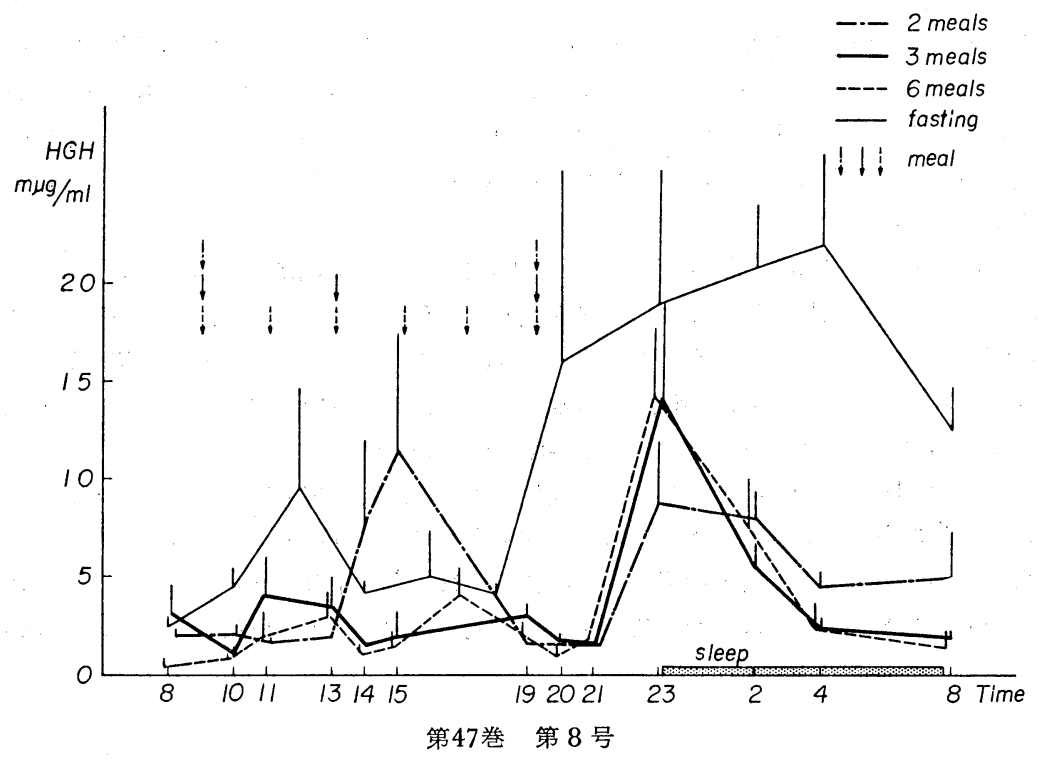


Fig. 6. Mean 24 hour blood sugar, IRI, FFA, and HGH levels during four experimental schedules in each of eight healthy subjects and Mean \pm S.E.
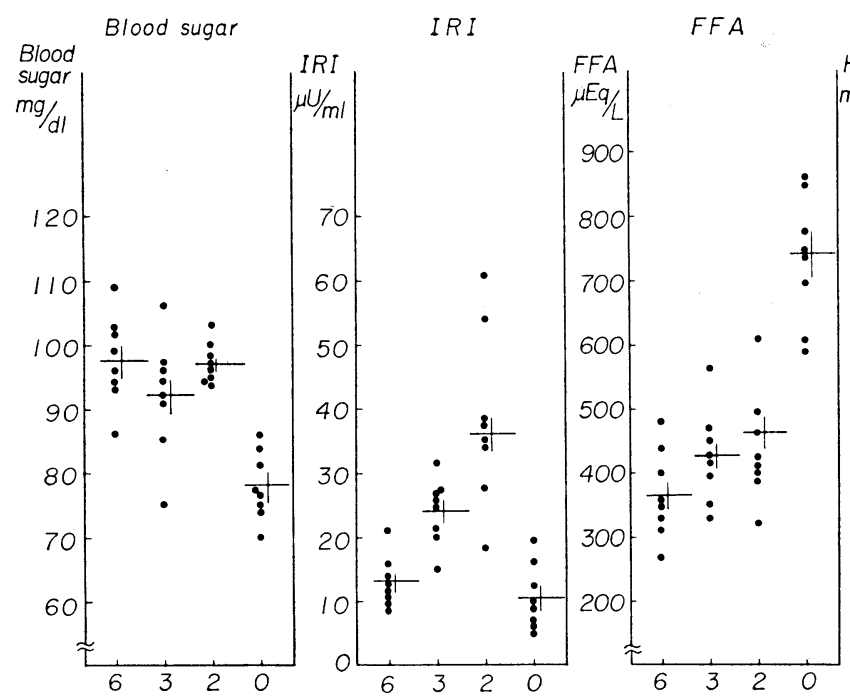

$H G H$

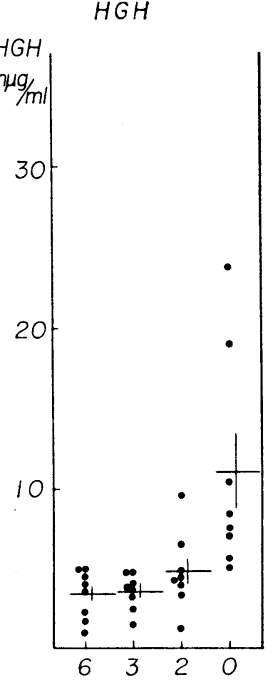

血糖と IRI の関係をみると，両者の間に有意の正相関が認められた $(\mathrm{r}=0.4934, \mathrm{~N}=333 . \mathrm{p}<0.01)$.

$\mathrm{HGH}$ と FFA の関係をみると, 各測定時の両者の間に相関は認められなかつたが，1 日平均值では, 有 意の正相関が認められた $(\mathrm{r}=0.6032 \mathrm{~N}=31 \mathrm{P}<0.01)$.

各測定時の $\mathrm{HGH}$ と IRI, HGH と血糖の間に相関はなかつた. HGH の peak とその前後の血糖, IRI，FFA の上昇及び下降の間にも一定の傾向はみられなかつた。

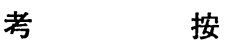

著者の実験では 6 回食, 3 回食, 2 回食のいずれにおいても, 朝食, 昼食後の血糖上昇に比し夕食後の血 糖上昇が大であつた。

これは午前と午後の耐糖能を糖負荷試験で比較してみると, 正常者において午後の耐糖能が低下するとい う Jarrett 等 ${ }^{15) \sim 17)}$ の成績と一致する。 その機序は不明であるが, Jarrett ${ }^{15)}$ は Insulin 分泌に日内変動があ り，1日のうちで午前中に最も多いという Rigas ${ }^{18)}$ や Freinke ${ }^{19)}$ らの報告より，刺激に対する Insulin 分 泌の差が耐糖能の差として現れるのではないかと考えている. しかし彼等の実験で Insulin 測定がなされ ていないので明確ではない．

著者の成績では Insulin 分泌は夕方に多く，血糖との間に有意の正相関が認められた．とのととは血糖 に日内変動があり，IRI は血糖上昇に従つて分泌されるてとを示している．血糖に日内変動の生に゙る原因は ての実験では明かでない. Staub 効果を考慮して食事間隔が影響しているとすると, 朝食前13時間に比し, 夕食前は 3 回食で 6 時間, 2 回食では 10 時間であるのに, 夕食後の血糖上昇が大なるてとより考えにくい. Hyner $ら^{20)}$ は 5 時間以上の食事間隔があれば食事の影響はないという.

成長ホルモンに diabetogenic action があり, 成長ホルモン投与は耐糖能を低下させるととが知られてい $ろ^{21)}$. Yalow ${ }^{22)}$ らは糖負荷試験を 3，4，6 時間の間隔をあけてくりかえしたとき，2回めの耐糖能異常は 1 回めの糖負荷後の成長ホルモン分泌の多いものに認められることより, 成長ホルモンの耐糖能に及ぼす影 響を重視している，著者の実験では，夕食前 $\mathrm{HGH}$ と夕食後血糖の間に関係はみられず，HGH の影響は 不明である. 
夕食前 FFA と夕食後血糖の間には有意の逆相関が認められる $(\mathrm{r}=0.7324 \mathrm{~N}=23 \mathrm{p}<0.01)$ ので, 夕食 前 FFA 高值が夕食後の耐糖能低下に関連しているかもしれない。

人間で食事回数の代謝に及ぼす影響が注目されている. Fábby $ら^{6)}$ は平常生活をしている人を食事回数に よりわけて観察したとてろ, 食事回数の少い群ほど高コレステロール血症, 耐糖能異常を高頻度に認めた.

Gwinup $ら^{578)}$ は同一カロリーの 1 日量を 1 回， 3 回，10回に投与し， 2 週間後に糖負荷試験を施行したとて ろ, 食事回数の少い期間後に耐糖能異常と血清コレステロール，リン脂質，FFA の増加を認めた。彼らは 食事回数を減らしたととに対する適灾として lipogenesis と glucon ogenesis が増加し, 血中 FFA 増加 が肝における血清脂質の増加をひきおてすと考えている. Bortz $ら^{9)}$ も同一カ口リ一食を 1 回, 3 回, 9 回 に分割投与すると， 1 回食で耐糖能低下，FFA 高值を認めた。

著者の実験では, 食事回数の少いほど夕食後の血糖上昇著しく, 2 回食で 8 名中 4 名に食後 1 時間值が $180 \mathrm{mg} / \mathrm{dl}$ 以上の異常を認めた。また FFA も食事回数の少いほど高值を示し，Gwinup らや Bortz らの 報告と一致する成績であつた。

食事回数の変化は体脂肪の増加や肥満に影響を与えることは動物実験で多くの報告がある ${ }^{1) ~ 3) 23) ~ 25) ~ C o h n ~}$ ${ }^{3) 233}$. らは自由食の rats と 1 回食の rats を比較したとき, 1 回食の rats は自由食の rats と同一または $80 \%$ の食事摄取量にもかかわらず， 2 週間後の組織構成は，自由食群では水 $67.8 \%$, 脂肪 $7.8 \%$, 蛋白 22.4 $\%, 1$ 回食群では水 $55.8 \%$, 脂肪 $23.8 \%$, 蛋白 $17.7 \%$ となり, 後者で著しい体脂肪の増加を認めた. Leveille $ら^{24225)}$ は自由食と 1 回食の rats を16週間観察し, 1 回食群は自由食群の70 75\%の食事搷取量にもかかわ らず，同程度の体重増加をみている。

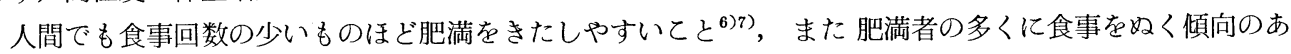
るとと ${ }^{26)}, 1$ 日の摄取カロリ一の大部分を夕方にとる night eating syndrome のみられるととが知られて いる ${ }^{27)}$.

rats における実験成績及びてれらの報告は，撕取カロリ一のみでなく，食事回数の肥満に及ぼす影響の重 要さを示している.すなわち食事回数の少いほでエネルギー代謝が経済的に行われ，肥満すると考えられる 2)4)10)24)25).

Rubner は（1902年）生体が基礎代謝の状態で摄取した食物が，消化吸収されて体内に貯蔵されるときの エネルギーは熱として測定されるととを観察し，乙れを食物の特異動的作用 (specific dynamic actiyn, 以下 SDA と省略）と呼んだ、SDA は熱として消費され, 食物のもつ熱量からての熱量をひいた残りが史 際に生体に利用される熱量であるから, 体重調節に際し重要な役割を果すと考元られる

$\mathrm{SDA}$ は食物の各栄養素により異り，蛋白質で $30 \% ，$ 糖, 脂肪では各々 $6 \% ， 4 \%$ あるるといわれるが， 混合食を摄取するとき，各栄養素の割合及び摄取量によつて変化するてとが知られている ${ }^{2931) ~ 35) . ~ そ し て ~}$


SDA は被験者の栄養状態 ${ }^{35363)}$ や運動 ${ }^{29}$ によつても変化する.

エネルギー代謝について考えるとき，SDA のほかに運動及び基礎代謝についても考慮せねばならない． 食事回数とエネルギー代謝に関しては, Leveille は ${ }^{37)} 1$ 回食の rats で運動の減少を認め, 従つてエネルギ 一消費の少いとと Cohn らは 1 回食 rats で甲状腺のI $\mathbf{I}^{131}$ 撕取率が自由食 rats の $50 \%$ と低下しているととよ り，食事回数を少くするてとは甲状腺機能位下をひきおてし肥満の原因の 1 つになると考えている2．また Fábby $~^{38}$ は rats で間歇的絶食を行うと，24時間 $\mathrm{O}_{2}$ 消費量は対移に比し少いという. Kekwick らは自由 食 rats は 1 回食 rats に比し, 体重及び体脂肪の増加を認めたが, てれは運動及び 基礎代謝によるエネル ギー消費に両者の差がないととから SDA の差であると述べている ${ }^{33)}$.

人間でも同一カロリ一を摂取するとき，食事回数の少いほど lipogenesis の増加及び肥満をきたしやすい ことは, SDA が少くてすむてとによると考えられている ${ }^{4) 10}$ )29). しかし SDA の直接の機序は現在のとて ろなお不明であり, 中間代謝を追求する上で興味ある対移となつている ${ }^{36)}$.

Cohn $ら^{2)} 11$ 回食の rats で Glucose-6-phosphate dehydrogenase, Leveille $ら^{39} は$ hexokinase, $\alpha$-gly- 
cerophosphate dehydrogenase 等の lipogenesis 亿必要な enzyme 活性, 及び pyruvate carboxylase 等 の glucogenesis に関する enzyme 活性の増加を認め, 食事回数を少くするてとは体内の中間代謝課程に 変化をもたらすととを示した。

Insulin の糖代謝のみでなく，脂質代謝に及ぼす作用，すなわち Insulin により脂肪組織での糖利用が 増し， $\alpha$-glycerophosphate の産生が増加して，中性脂肪の合成が容易になるてと，また脂肪組織からの FFA 放出が阻止されること ${ }^{40) 41)}$ ，さらに Insulin には蛋白合成促進作用のあること年を考えると，Insulin が energy 代謝に及ぼす影響は大きいと思われる。

Leveille ${ }^{39)}$ Insulin 分泌増加または Insulin 感受性の増加が glucose 利用を促進し, また lipogenesis 等に関する種々の enzyme 活性を高め, 1 回食 ratsにおける代謝の調節に関与しているのではないかと述 べている.

Mosinger によると間歇的に多食をする rats では Insulin-like activity の増加が認められるというう3). Braun $~^{44)}$ は rats で食事回数を少くすると, Insulin 投与による低血糖が著明にみられることから, Insulin の糖代謝に及ぼす作用が增強されるてと，また脂肪組織において lipid と glycogen 合成促進のあるてと から，脂肪組織での Insulin 感受性が増大しているという。てれらの動物実験の結果は人間の肥満にもあて はめて考えることができると思わ执る5) 8)28).

しかし, 食事回数の Insulin 分泌に与える影響についての報告はほとんどみられない. Bortz ら ${ }^{99}$ 及び Glick $~^{45)}$ は食事回数による Insulin 分泌江差が認められなかつたという.

著者の実験では食事回数の少いほど IRI 増加を認め, 特に夕食後その差は有意であり, 1 日平均 IRI 值 からみても食事回数の少いほど有意に高值を示した。乙の成績は食事回数の少いほど肥満になりやすいとと と関係するのではあるまいか，すなわち生理的な状態で Insulin 分泌が多いというととは，エネルギー代 謝が経済的に行われることと関連すると思われるからである. また朝食及び㡺食後に比し夕食後に血糖と IRI 増加が大きいという著者の実験結果は, 夕食に 1 日の多くの搷取カロリーをとるという食習慣が，さら に肥満や耐糖能低下を生じやすくすると思われる。

成長ホルモンは末梢での糖利用を抑制して脂肪を動員し, また蛋白合成的に作用して代謝に重要な役割を 有するものと考光られている ${ }^{2146447)}$.

Glick $ら^{45)}$ は健康者 4 名につき一定の食事を 1 日 3 回及び 30 分毎に投与し, HGH の変動を観察し, また 絶食時の成績についてもふれている。 その結果, 絶食では HGH 分泌増加を認めたが, 食事回数による差 は認めなかつた，著者の実験でも，各測定時及び 1 日平均值において，絶食では $\mathrm{HGH}$ 增加をみたが, 食 事回数による差は認められなかつた。乙の事実は HGH が食事回数による energy 代謝にあまり関与しな いことを意味するものであろう。

成長ホルモンの脂肪動員作用は, 絶対的, 相対的 energy substate 不足時に発揮されるという ${ }^{47) 48)}$. Hunter ${ }^{49)}$ らは絶食状態における HGH のFFA 動員に対する役割を重視し, HGH は FFA 動員に際して triggering action をもつと考えている. しかしてれには Guabbe ら ${ }^{50)}$, Cahill ${ }^{51)}$ らの反論もみられる。

著者の実験では各測定時における HGH と FFA の間に相関はなかつたが，1 日平均 HGH 值と 1 日 平均 FFA 值の間には有意の正相関が認められるので，HGH の FFA 動員に対する作用は一既に否定で きないと思う. 将来症例及び採血回数を增しててれらの関係を明確にしょうと思う.

以上, 著者の実験から Insulin 分泌が食事回数の少いほど増加するととが明確となつた。乙れは食事回 数の少いほどエネルギー代謝が経済的に行われ，SDA が少いととと関連すると思われる.

従来, ホルモンの SDA に関する知見は少い. Adrenectomy, thyroidectomy, hypophysectomy は SDA を消失させると考えられていたが，現在では否定されている ${ }^{3552)}$. epinephxine の熱生産作用は既知の事実 であり, 肉摄取後尿中 epinephrine, noradrenaline 増加をみるという報告があるので，てれは SDA に一 部関与するかもしれない ${ }^{52)}$.

そのほか，近年，Dawkin ら ${ }^{53}$ は熱産生の機序として “lipolysis-fatty acid theory”を述へている。す す 
わち lipolysis によつて生じた fatty acid の酸化及び中性脂肪再合成の課程で熱産生があるという. Stirling $ら^{30)}$ は食事による熱産生を lipolysis-fatty acid theory に求めるてとができようと述べている。さ らに， $\alpha$-glycerophosphate の酸化え進が熱産生をますという報告もあり ${ }^{30) 53}$, 熱産生における糖や脂肪の 中間代謝及びホルモン作用は今後追求されるべき分野であろう.

著者の成績は 1 日だけ食事回数を変えた実験観察であるが，てれを長期持続したときには IRI 及び HGH の作用についてあらたな知見が得られるととであろう.

\section{結 論}

健康者 8 名について同一カロリーを 1 日 2 回, 3 回, 6 回に摄取した場合及び36時間の絶食を行い, 血糖, IRI, FFA, HGH に差があるかどうか検討した結果, 次の如き知見を得た。

1. 食事摄取時, 食後の血糖及び IRI 増加は朝食後, 昼食後に比し夕食後に大きく, また食事回数の少 いほどその上昇は大であつた。1 日平均血糖值は食事回数による差は認められなかつたが，1 日平均 IRI 值は食事回数の少いはど高值を示した。

2. 絶食時, 血糖及び IRIは漸減した。

3. FFA は食事回数の少いほど㡺の変動大きく, 特に夕食前の増加は, その差が著明であつた。1 日平 均 FFA 值は食事回数の少いほど大であつた。絶食時 FFA は漸増した。

4. HGH は食事回数により差は認められなかつたが, 絶食では著明な分泌増加をみた。

以上の成績から, 夕食後の IRI 増加は朝食, 昼食後に比し大であり, 食事回数の少いほど著しく, また 1 日平均 IRI 值よりみても食事回数の少いほど大である。乙のととは，1 日のカロリ一の大部分を夕食に 摄取する人や，食事回数の少い人ほど肥満をきたしやすいととと関連すると思われる，従来その差はSDA であろうとされているが，著者の成績からはてのインスリン反応の差が大きく関与すると考兵たい．

稿を終るに当り, 終始御㢳篤なる御指導を睗わつた浅野誠一教授, 松木駿助教授, 片岡邦三講師に深甚な 謝意を捧げます。また種々の御援助をいただいた厚治秀行博士はじめ内分泌代謝研究室各位に心から感謝い たします。

尚本論文の要旨は第44回日本内分泌学会総会において発表した。

\section{文献}

1) Hollifield, G. and W. Parson : J. Clin. Invesl. $41: 250$, (1962). $\quad$ 2) Gohn, G. and D. Joseph : Metabolism, $9:$ 492, (1960). 3) Van, Putten, L.M., D.W. Van Bekkum and A. Querido : Metabolism, $4: 68$, (1955). 4) 浅野誠一, 松木 駿: 日本医事新報, $2128: 23$ (1965). 5) Gwinup, G., R.C. Byron, W.H. Roush, F.A. Kruger and G.J. Hamwi : Amer. J. Nut. 13 : 209, (1963). 6) Fábby, P., J. Fodor, Z. Hezl and T. Braun : Lancet $2: 614$, (1964). 7) Fábby, P. : Amer. J. Clin. Nut. 18 : 358, (1966).

8) Gwinup, G., R.C. Byron, W.H. Roush and G.J. Hamwi : Lancet $2: 165$, (1963). 9) Bortz, W.M., P. Howat and W.L. Holmes : Metabolism, $18: 120$, (1969).

10）松木 駿, 厚治秀行 : 内科, $19: 647,(1967)$.

松木 駿, 谷田良作, 関屋 寛: ホルモンと臨床, $3: 625,(1955) . \quad 12)$ 厚治秀行 : 慶応医学, 46 : 161, (1969). 13) Morgan, C.R. : Proc. Soc. Exp. Biol. Med. 121 : 62, (1966). 小山勝一 : 臨床病理, $13: 474$, (1968). 15) Jarrett, R.J. and H. Keen : Brit. Med. J. 2 : 341, (1969). 16) Robert, H.J. : J. Amer. Geriat. Soc. $12: 423$, (1964). 17) Bowen, A.J. and R.L. Reeves : Arch. Int. Med. $119: 261$, (1967). 18) Rigas, A.N. : Brit. Med. J. 4 : 25, (1968). 19) Freinkel, N. : J. Lab. Clin. Med. Med. $71: 171$, (1968). Hayner, N.S. : Diabetes, $14: 413$, (1963).

21) Luft, R. and E. Cerasi : Diabetologia, $4: 1$, 
(1968).

22) Yalow, R.S., S.J. Goldsmith and S.A. Berson : Diabetes, 18 : 402, (1969).

23) Cohn, C. and D. Joseph : Amer. J. Physiol. 196 : 965, (1959).

24) Leveille, G.A. and

E.K. O'Hea : J. Nutrition, 93 : 541, (1967).

25) Leveille, G.A. and R.W. Hansen : Can. J. Physiol. Pharmacol. 43 : 857, (1965).

26) Monello, L.F. : Ann. N.Y. Acad. Sci. $131: 593$,

(1965). 27) Stunlard, A.J., W.J. Grace and H.G. Wolff : Amer. J. Med. 19 : 78, (1955). 28)

内藤周幸：：最新医学, $22: 1742$, (1967). 29$)$ Miller, D.S. and P. Mumford : Proc. Nutr. Soc. 25 : 100, (1966). $\quad 30)$ Stirling, J.L. and M.J. Stock : Nature, $220: 801$, (1969). 31) Miller, D.S. and P. Mumford : Amer. J. Glin. Nut. $20: 1212$, (1967). $\quad 32$ ) Miller, D.S. and P. Mumford : Amer. J. Clin. Nut. 20 : 1223, (1967).

33) Kekwick,A. and G.L.S. Pawan : Ann. N.Y. Acad. Sci. 131 : 519, (1965).

35) Wilhelmj, G.M. : Physiol. Rev. 15 : 202, (1935). 34) Keeton, R.W. : Nut. Rev. 7 : 22, (1949). 36）柳金太郎：代謝, (1958), 50, 医学書 院, 東京. 37) Leveille, G.A. and K. Chakrabarty : J. Nutrition, 93 : 546, (1967). 38) Fàbby, P., R. Petràsek, E. Horàkovà, E. Konopàsek and T. Baum : Brit. J. Nut. 19 : 295, (1963). 39) Leveille, G.A. and K. Chakrabarty : J. Nutrition, $96: 76$, (1968). 40) 福崎 恒: 臨床科学, 4 : 197, (1968). $\quad 41)$ Williams, R.H. : Diabetes, 1st ed. 1968, 129, Dokutaru Co. Ltd., London. 42) Williams, R.H. : Diabete, 1st ed. (1968), 121, Dokutaru Co. Ltd., London. 43) Tepperman, H.M. and J. Tepperman : Fed. Proc. $23: 73$, (1964). 44. Braun, T., A. Vràna and P. Fàbby : Experientia, $23: 468$, (1967). 45) Pecile, A. and E.E. Muller : Growth Hormone, 1st. ed. (1968), 84, Amsterdam. 46) Rabinowitz, D., G.A. Klassen and K.L. Zierler : J. Glin. Invest. $44: 51$, (1965). 47）井村裕夫, 加藤 譲: ホルモンと臨床, $18: 803$, (1970). 48) Glick, S.M., J. Roth, R.S. Yalow and S.A. Berson : Rec. Prog. Hormone Res. 21 : 241, (1965). 49) Hunter, W.M., J.A.R. Friend and J.A. Strong : J. Endocr. $34: 139$, (1966). 50) Quabbe, H.J., E. Schilling and H. Helge : J. Endocr. 26 : 1173, (1966).

51) Cahill, G.F., Reichard, and D.M. Kipnis : J. Glin. Invest. $45: 1751$, (1966). 52) Duncan, G.G. : Diseases of Metabolism, 5th ed. (1964), 27, Saunders Co., Philadelphia. 53) Dawkins, M.J.R. and D. Hull : J. Physiol. 172 : 210, (1964).

54) Bray, G.A. : Lancet, 2 : 397, (1969). 